\title{
Reactivation of coeliac disease after third pregnancy
}

\author{
Üçüncü gebelik sonrası tekrar aktifleşen çölyak hastalı̆̆ı \\ Nazmiye Dinçer*, Firdevs Topal, Fatih Esad Topal
}

Department of Pathology (N. Dinçer, MD), Yıldırım Beyazıt University, Atatürk Teaching and Research Hospital, TR-06800 Ankara, Department of Gastroenterology (F. Topal, MD), Department of Emergency (F. E. Topal, MD), Cankiri State Hospital, TR-18100, Çankırı.

\begin{abstract}
Coeliac disease is a common autoimmune disorder that can be seen in genetically susceptible people with exposure to gluten proteins. This report describes a case of a 27 -year-old woman who was diagnosed as coeliac disease at 2 years old and was on a gluten-free diet until 15 years old. She remained symptom-free without gluten-free diet for 12 years during which she experienced two problem-free pregnancies. One month after she gave birth to her child after third pregnancy, coeliac disease recurred. Coeliac disease must be taken into consideration, in the period after birth in patients with diarrhea, fatigue and abdominal pain.
\end{abstract}

Keywords: Coeliac Disease, pregnancy, gluten-free diet

Özet

Çölyak hastalığı, genetik olarak yatkın kişilerde, gluten proteinine maruz kalındığında görülebilen yaygın otoimmün bir hastalıktır. Olgumuz 2 yaşında Çölyak hastalığı tanısı almış, 15 yaşına kadar glutensiz diyet uygulamış, 27 yaşında bayan hastadır. Olgumuz 12 yıl boyunca glutensiz diyet yapmadan, semptomsuz ve problemsiz iki gebelik geçirmiştir. Üçüncü gebeliği takiben doğumdan 1 ay sonra Çölyak hastalığı nüksetmiştir. Çölyak hastalığı, doğumdan sonraki dönemde, diyare, yorgunluk ve karın ağrısı olan hastalarda mutlaka göz önünde bulundurulmalıdır.

Anahtar sözcükler: Çölyak hastalığı, gebelik, glutensiz diyet

Geliş tarihi/Received: March 14, 2012; Kabul tarihi/Accepted: April 26, 2012

*Corresponding author:

Dr. Nazmiye Dinçer, Patoloji Bölümü, Yıldırım Beyazıt Üniversitesi, Atatürk Eğitim ve Araştırma Hastanesi,TR-06800 Ankara. E-mail: nazmiye_karaman@yahoo.com

\section{Introduction}

Coeliac disease, also known as gluten-sensitive enteropathy, is a common autoimmune disorder associated with enteropathy and malabsorption which can be seen in genetically predisposed people of all ages with exposure to gluten proteins [1, 2]. Coeliac disease may present during pregnancy or during the postpartum period. Previous studies have suggested that in some cases, pregnancy was concerned in the presentation or reactivation of coeliac disease; and in some cases, presentation of the disease during the puerperium were reported [3].

\section{Case report}

A 27-year-old female patient was referred to our gastroenterology outpatient clinic with the complaints of diarrhea, fatigue, abdominal pain, nausea and contractions. Questioning revealed that she was diagnosed as coeliac disease at 2 years old and was on gluten-free diet until 15 years old. After 15 years old, she started gluten-containing diet and no symptoms were seen for 12 years. During this time she got married and she experienced two problem-free pregnancies. However, she concealed her disease from her husband and relatives. The symptoms developed since one month after she delivered a healthy infant on the 38th week of her third pregnancy. Her body temperature was $37^{\circ} \mathrm{C}$, and her blood 
pressure was $120 / 80 \mathrm{mmHg}$ with a pulse rate of 85 beats/min. Physical examination revealed no abnormality. Laboratory values were as follows: hemoglobin, $11.9 \mathrm{mg} / \mathrm{dL}$; white blood cell count, $4206 / \mathrm{mm}^{3}$; platelets, $300,000 / \mathrm{mm}^{3}$; serum levels of calcium, blood urea nitrogen (BUN), creatinine, albumin, alanine aminotransferase (ALT) and aspartate aminotransferase (AST) were $7,6 \mathrm{mg} / \mathrm{dL}(9-10,5 \mathrm{mg} / \mathrm{dL}) ; 11 \mathrm{mg} / \mathrm{dL} ; 0,72$ $\mathrm{mg} / \mathrm{dL} ; 3,1 \mathrm{~g} / \mathrm{dL}(3,5-5 \mathrm{~g} / \mathrm{dL}) ; 89 \mathrm{IU} / \mathrm{L}(5-40 \mathrm{IU} / \mathrm{L})$ and $107 \mathrm{IU} / \mathrm{L}(8-33 \mathrm{IU} / \mathrm{L})$, respectively; the other routine laboratory tests were within normal range. Hence, we detected hypocalcemia and hypoalbuminemia on the boundary, and elevated liver enzymes. Serological blood tests for anti-endomysium and anti-transglutaminase antibodies were strongly positive. In endoscopic examination, duodenal mucosa showed edema, mosaic pattern and flattening of the duodenal folds. Pathological examination of biopsies obtained from the second portion of the duodenum revealed subtotal villous atrophy and a marked increase in the number of intraepithelial lymphocytes (Figure 1). The crypts were elongated and hyperplastic, which showed increased mitotic figures; and also increase in plasma cells, chronic inflammatory cells and occasionally a few polymorphonuclear leukocytes were detected in lamina propria (Figure 2). After the diagnosis of coeliac disease, the patient responded to gluten-free diet and her symptoms regressed within days and weeks.

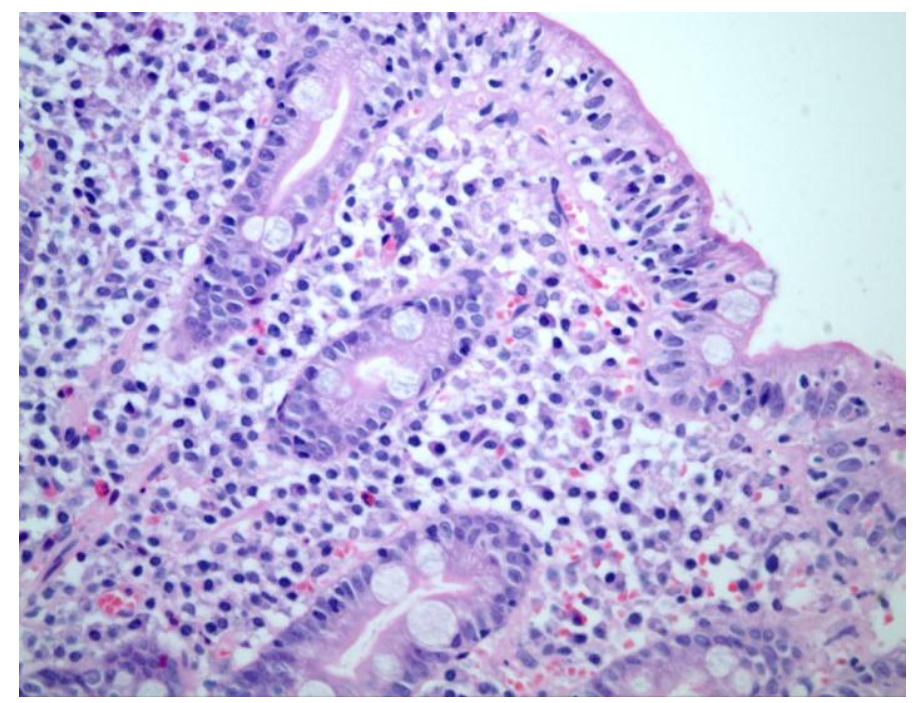

Figure 1. Villous atrophy and a marked increase in the number of intraepithelial lymphocytes (X20).

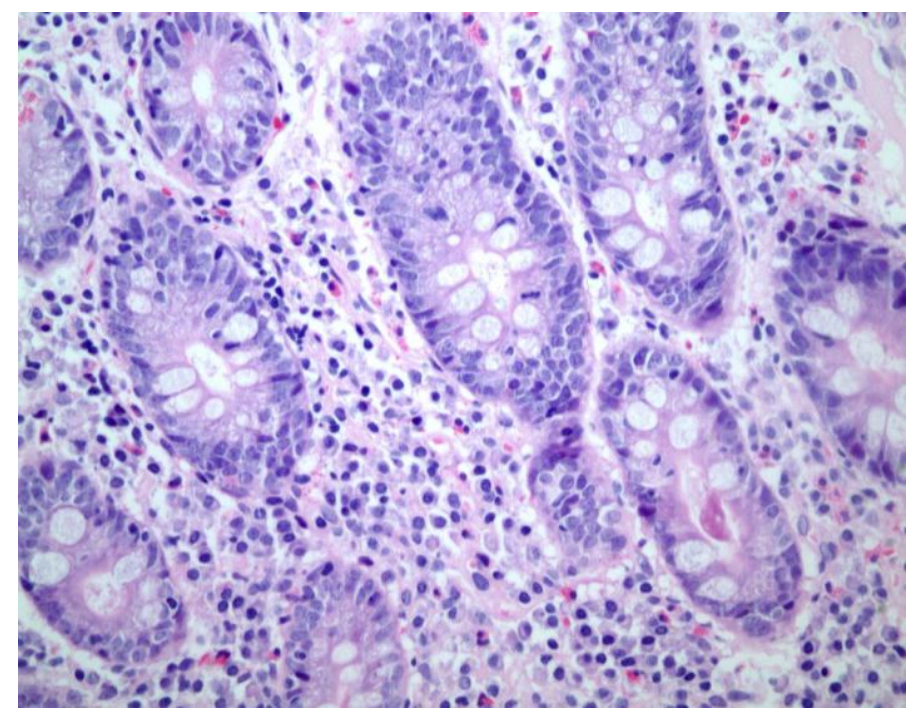

Figure 2. Elongated and hyperplastic crypts showed increased mitotic figures; and the number of plasma cells was increased in lamina propria (X40). 


\section{Discussion}

Untreated coeliac disease may be related with adverse pregnancy-related events and outcomes such as intrauterine growth retardation, having babies with low birth weight, higher incidence of abortion and repeated miscarriage [4]. In Europe and the United States, the epidemiological studies indicate that coeliac disease is far more common than previously realized and that the prevalence of coeliac disease is approximately $1 \%$ in the general population $[1,5]$. To prevent or cure its manifestations, a strict gluten-free diet is the only treatment for coeliac disease to date [5]. The symptoms of coeliac disease vary widely from patient to patient, depending on patient's age, the duration of the disease, and presence of extra intestinal evidences such as anemia, infertility, bone fractures and dermatitis herpetiformis [2]. Coeliac disease presents between the ages of 4 to 24 months in infants with symptoms of growth retardation, diarrhea, vomiting and abdominal bloating [6]. The onset of symptoms follows the introduction of gluten proteins into the diet. Adult coeliac disease has a wide spectrum of clinical manifestations such as chronic diarrhea, abdominal bloating or weight loss; however, some patients have virtually no symptoms [7]. Previous research has suggested that coeliac disease is likely to be associated with elevated risk of adverse pregnancy-related events and decrease in fertility [8]. Also these patients might have a miscarriage or babies with low birth weight, intrauterine growth retardation, a shorter duration of breastfeeding and additionally many of pregnancy-related complications like these could be seen $[4,8]$. In Europe, children were re-started to gluten containing diet after a variable period of being on a gluten-free diet. Recent evidence reveals that in cases supposed to be cured, the symptoms of coeliac disease seem to disappear during late childhood or adolescence [9]. Unfortunately, later in life, among the patients of symptom-free adults with childhood diagnosis of coeliac disease, notable damage in small intestine and important vitamin and mineral deficiencies can be detected $[1,2]$. Besides, in a recent study, the results suggested that gluten-free diet during early childhood might have a long-term protective effect in adults from gluten-related diseases [10]. As presented in our case, it is remarkable and interesting that the patient remained symptom-free without gluten-free diet for 12 years and experienced three healthy pregnancies, and than one month after she gave birth to third child, coeliac disease reactivated during the puerperium. It is important to take into consideration that if gluten is reintroduced to the diet, a relapse of the disease will occur sooner or later. As suggested in related studies, gluten-free diet on early childhood, as in our case, might have long term protective effect on coeliac disease for the future life. Early diagnosis of coeliac disease during pregnancy or puerperium is important to prevent complications caused by disease, as presented in our case, especially in patients who hide their disease because of social and environmental reasons. There are a number of case reports of patients with coeliac disease presented during pregnancy or puerperium, but an adult with a childhood diagnosis of coeliac disease who remained symptom-free for more than a decade, having a reoccurrence after third pregnancy during puerperium is an interesting case. Although it remains in remission for many years in which several problem-free pregnancies were experienced without gluten-free diet, coeliac disease may reactivate after subsequent pregnancies. In conclusion, coeliac disease must be taken into consideration in patients with diarrhea, fatigue and abdominal pain in the postnatal period.

\section{References}

1. Green PH, Jabri B. Coeliac disease. Lancet 2003; 362: 383-91.

2. Farrell RJ, Kelly CP. Celiac sprue. N Engl J Med 2002; 346: 180-8.

3. Erdozain JC, Martin de Argila C, Cerezo E, Lizasoain J, Presa M. Adult celiac disease: reactivation during pregnancy and puerperium. Am J Gastroenterol 1993; 88: 1139-40.

4. Martinelli P, Troncone R, Paparo F, Torre P, Trapanese E, Fasano C, Lamberti A, Budillon G, Nardone G, Greco L. Coeliac disease and unfavourable outcome of 
pregnancy. Gut 2000; 46: 332-5.

5. Trier JS. Celiac sprue. N Engl J Med 1991; 325: 1709-19.

6. Catassi C, Fabiani E. The spectrum of coeliac disease in children. Baillieres Clin Gastroenterol 1997; 11: 485-507.

7. Corazza GR, Gasbarrini G. Coeliac disease in adults. Baillieres Clin Gastroenterol 1995; 9: 329-50.

8. Rostami K, Steegers EA, Wong WY, Braat DD, Steegers-Theunissen RP. Coeliac disease and reproductive disorders: a neglected association. Eur J Obstet Gynecol Reprod Biol 2001; 96: 146-9.

9. Kumar PJ, O'Donoghue DP, Stenson K, Dawson AM. Reintroduction of gluten in adults and children with treated coeliac disease. Gut 1979; 20: 743-9.

10. Ciacci C, Iovino P, Amoruso D, Siniscalchi M, Tortora R, Di Gilio A, Fusco M, Mazzacca G. Grown-up coeliac children: the effects of only a few years on a gluten-free diet in childhood. Aliment Pharmacol Ther 2005; 21: 421-9. 